\title{
Assessment method for the ecological status of Estonian coastal waters based on submerged aquatic vegetation
}

\author{
K. Torn \& G. Martin \\ Estonian Marine Institute, University of Tartu, Estonia
}

\begin{abstract}
In this paper water quality assessment system of Estonian coastal sea areas using submerged aquatic vegetation according to the Water Framework Directive of the European Community is described. Estonian coastal waters are divided to 6 national types covering 16 water bodies. The assessment system is based on three monitoring areas for each water body. Three metrics are used for water quality classification system based on phytobenthos: 1) the depth distribution of phytobenthos as the deepest occurrence of a single attached specimen; 2) the maximum depth distribution of Fucus vesiculosus as the deepest occurrence of singe plant specimens; 3) the proportion of perennial plant species in the observed community based on dry biomass of attached erect vegetation.
\end{abstract}

Keywords: classification, coastal water, phytobenthos, water framework directive, ecological quality.

\section{Introduction}

In connection with the implementation of the EU Water Framework Directive (WFD) in the area of assessment of the ecological status of water bodies, the classification system should be developed. Classification systems should be based on different biological water quality elements indicating the status of water bodies. According to the WFD, three biological quality elements (phytoplankton, benthic invertebrate fauna and aquatic flora) should be used for coastal waters [1].

The principle of the whole assessment procedure is to measure deviation from reference condition. According to the normative definition of the WFD, reference conditions represent a status with no or only minor anthropogenic 
impact. The actual description of reference conditions could be obtained from historical records, modelling exercise or even using an expert opinion. The determination of the ecological status has to be done type-specifically, which means for each type of coastal water reference conditions have to be identified. Biological indicators or metrics used in the assessment system have to react on different levels of anthropogenic pressure. Ecological status assessments shall permit classification of water bodies into five classes - poor, bad, moderate, good and high. The WFD requires that good ecological status of surface water should achieved by 2015 [1].

Aquatic vegetation is used for assessment of water quality for decades both in fresh-water and marine environment [2]. Phytobenthos is good indicator of aquatic environmental health because the autotrophic species inhabiting the phytobenthos zone respond to changes in nutrient concentrations, light climate, toxic contaminants, mechanical stress and other human induced pressures. Responses of the macrophyte community to environmental stress could be regarded as an early warning signal of the community and ecosystem impairment [3]. Eutrophication influences different aspects of underwater vegetation, well documented are the decrease of biodiversity, decrease in vegetation depth penetration, substitution of perennial species with opportunistic filamentous algae $[4,5]$. As most of the anthropogenic pressures cause alterations in the physical environment characteristics followed by short- or long-term effects in benthic communities, phytobenthos has proved to be very useful as integrating (both in time and space) biological indicator for conditions of coastal environment.

A national water quality classification system for surface waters based on type specific reference conditions and fulfilling requirements of EU WFD was established in Estonia during early 2007. Here, we present an overview and description of the developed monitoring method and assessment system for implementing the Water Framework Directive based on indicators reflecting the status of phytobenthos in Estonian coastal waters.

\section{Method description}

\subsection{Estonian national typology of coastal waters}

Estonia governs approximately $50000 \mathrm{~km}^{2}$ of the Baltic Sea area of which about $10000 \mathrm{~km}^{2}$ belongs to the coastal waters according to WFD definitions (sea area extending up to $1 \mathrm{~nm}$ from the baseline). Estonian coastal sea is divided into six national types. Coastal water types are defined on the basis of hydromorphological conditions as salinity $(<0.5,0.5$ to $5-6,5-6$ to $18-20,18-20$ to $30,>30)$, depth $(<30 \mathrm{~m},>30 \mathrm{~m})$, exposure to waves (extremely exposed, very exposed, exposed, moderately exposed, sheltered, very sheltered), mixing conditions (fully mixed, seasonally mixed, permanently mixed), water residence time (days, weeks months), dominating substratum (mud-silt, sand-gravel, cobble-hard rock, mixed sediment) and duration of ice cover (irregular, $<90$ days, $90-150$ days, $>150$ days (Table 1 ). Ranges of factors are predetermined by 
Guidance document [6]. Due to the natural character of the Baltic Sea the actual salinity range of surface water in Estonian coastal area does not exceed 7.5.

Table 1: $\quad$ Description of national types (based on [7]).

\begin{tabular}{|c|c|c|c|}
\hline Name of type & $\begin{array}{c}\text { Southeastern } \\
\text { Gulf of Finland }\end{array}$ & Pärnu Bay & $\begin{array}{l}\text { Western Gulf of } \\
\text { Finland }\end{array}$ \\
\hline Code of type & I & II & III \\
\hline Salinity (psu) & $0.5-(5-6)$ & $0.5-(5-6)$ & $(5-6)-18$ \\
\hline Tidal range $(\mathrm{m})$ & $<1$ & $<1$ & $<1$ \\
\hline Depth (m) & $\begin{array}{l}<30 \\
>30 \\
\end{array}$ & $<30$ & $>30$ \\
\hline Wave exposure & exposed & $\begin{array}{c}\text { moderately } \\
\text { exposed }\end{array}$ & exposed \\
\hline $\begin{array}{c}\text { Mixing } \\
\text { conditions }\end{array}$ & seasonally mixed & fully mixed & $\begin{array}{c}\text { permanently } \\
\text { stratified }\end{array}$ \\
\hline Residence time & days & weeks & days \\
\hline Substratum & $\begin{array}{c}\text { sand-gravel } \\
\text { cobble-hard rock }\end{array}$ & $\begin{array}{c}\text { mud-silt } \\
\text { sand-gravel }\end{array}$ & mixed sediment \\
\hline Ice cover & 90-150 days & 90-150 days & $<90$ days \\
\hline Name of type & $\begin{array}{c}\text { Western } \\
\text { Archipelago }\end{array}$ & Väinameri & Gulf of Riga \\
\hline Code of type & IV & $\mathrm{V}$ & VI \\
\hline Salinity (psu) & $(5-6)-18$ & $(5-6)-18$ & $(5-6)-18$ \\
\hline Tidal range $(\mathrm{m})$ & $<1$ & $<1$ & $<1$ \\
\hline Depth (m) & $\begin{array}{l}<30 \\
>30 \\
\end{array}$ & $<30$ & $<30$ \\
\hline Wave exposure & exposed & very sheltered & $\begin{array}{c}\text { moderately } \\
\text { exposed, sheltered }\end{array}$ \\
\hline Mixing conditions & seasonally mixed & fully mixed & seasonally mixed \\
\hline Residence time & days & days & days \\
\hline Substratum & $\begin{array}{c}\text { sand-gravel } \\
\text { cobble-hard rock }\end{array}$ & $\begin{array}{c}\text { mud-silt } \\
\text { sand-gravel }\end{array}$ & mixed sediment \\
\hline Ice cover & irregular & 90-150 days & $<90$ days \\
\hline
\end{tabular}

The Estonian coastal sea area is divided into 16 water bodies (Fig.1). Among those 15 are characterised as natural water bodies and one is attributed the category of heavily modified water bodies. This is due to the dyke constructed more than 100 years ago dividing Väike Strait (strait between Muhu and Saaremaa islands) into two, more or less independent parts without actual water exchange.

In accordance with requirements of the WFD in water bodies which are identified as being at risk of failing to meet their environmental objectives, an operational monitoring programme is carried out. For this purpose, the initial assessment of the state of coastal water bodies was conducted on the bases of 


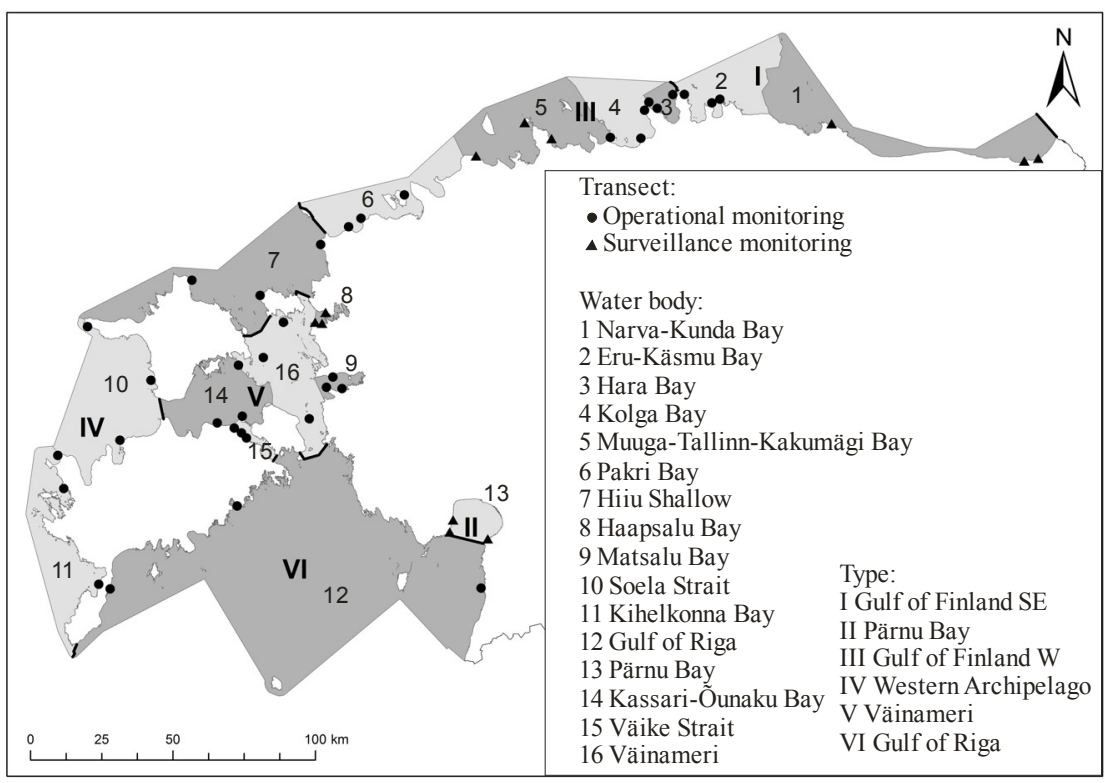

Figure 1: Location of transects, water bodies and types of coastal water in the Estonian coastal area.

previously existing information as well as data collected during the targeted monitoring programme. In Estonia 4 out of 16 water bodies are considered to be operational monitoring areas (Fig. 1). In this water bodies monitoring and assessments carried out every year during the 6 year assessment period. All other water bodies are monitored at least once during the assessment period within the surveillance monitoring programme.

\subsection{Sampling procedure for phytobenthos}

Each water body includes three phytobenthos monitoring areas. These areas were selected based on previous knowledge on the distribution of phytobenthic communities as well as the character of the dominating substrate. In each sampling area the monitoring transect is placed with fixed start and endpoint coordinates (Fig. 1). Monitoring activities are carried out once per year during the late summer season (July-August).

The Estonian monitoring method is based on HELCOM COMBINE guidelines [8]. Monitoring is carried out along the imaginary transect line placed at 90 degrees to the shoreline from a predetermined starting point. Observations are carried out after each $1 \mathrm{~m}$ of depth change. Coverage descriptions are done in a 3-4 m wide visibility corridor. Observations are carried out to the deepest limit of vegetation. When the deepest limit is reached the possible occurrence of deeper vegetation is checked by drop underwater video camera. Along the monitoring transect total coverage of phytobenthos community, coverage of individual species and character of substrate is registered. 
For a quantitative description of phytobenthic communities the biomass samples are obtained from each different community type. Depending on the length of the transect biomass samples are taken from 5-7 depth intervals. Most commonly samples from depths $0.2,0.5,1-2,2-3,4-5$ and 6-8 meters were collected. Quantitative biomass samples are taken always in three replicates, $20 \times 20 \mathrm{~cm}$ frames with attached bag are used. Samples are stored in a deep freezer and later sorted and determined to species level in a laboratory. Each species is dried separately at $60^{\circ} \mathrm{C}$ until constant weight is reached and the dry weight is measured with $0.0001 \mathrm{~g}$ accuracy.

\subsection{Metrics description}

In Estonia three phytobenthos metrics are used for water quality classification system: 1) depth distribution of phytobenthos 2) depth distribution of bladderwrack, Fucus vesiculosus 3) proportion of perennial plant species in the community. To determine the depth distribution of phytobenthos the deepest occurrence of single attached vegetation is obtained by scuba-diver or by drop video camera. To determine the maximum depth distribution of Fucus vesiculosus the deepest occurrence of singe plant specimens are determined visually by scuba-diver. Proportion of perennial plant species in the

Table 2: $\quad$ List of erect annual (A) and perennial (P) plant species.

\begin{tabular}{lclc}
\hline Species name & Lifetime & Species name & Lifetime \\
Aglaothamnion roseum & $\mathrm{A}$ & Monostroma balticum & $\mathrm{A}$ \\
Ceramium tenuicorne & $\mathrm{A}$ & Myriophyllum spicatum & $\mathrm{A}$ \\
Ceramium virgatum & $\mathrm{P}$ & Najas marina & $\mathrm{A}$ \\
Ceratophyllum demersum & $\mathrm{P}$ & Percursaria percursa & $\mathrm{P}$ \\
Chaetomorpha linum & $\mathrm{A}$ & Pilayella littoralis & $\mathrm{A}$ \\
Chara aspera & $\mathrm{A}$ & Polyides rotundus & $\mathrm{P}$ \\
Chara baltica & $\mathrm{A}$ & Polysiphonia fibrillosa & $\mathrm{A}$ \\
Chara canescens & $\mathrm{A}$ & Polysiphonia fucoides & $\mathrm{P}$ \\
Chara connivens & $\mathrm{A}$ & Potamogeton pectinatus & $\mathrm{A}$ \\
Chara horrida & $\mathrm{A}$ & Potamogeton perfoliatus & $\mathrm{A}$ \\
Chara tomentosa & $\mathrm{A}$ & Ranunculus baudotii & $\mathrm{A}$ \\
Chorda filum & $\mathrm{A}$ & Ranunculus circinatus & $\mathrm{A}$ \\
Chroodactylon ornatum & $\mathrm{A}$ & Rhizoclonium riparium & $\mathrm{A}$ \\
Cladophora glomerata & $\mathrm{A}$ & Rhodochorton purpureum & $\mathrm{P}$ \\
Cladophora rupestris & $\mathrm{P}$ & Rhodomela confervoides & $\mathrm{P}$ \\
Coccotylus truncatus & $\mathrm{P}$ & Ruppia cirrhosa & $\mathrm{A}$ \\
Dictyosiphon foeniculaceus & $\mathrm{A}$ & Ruppia maritima & $\mathrm{A}$ \\
Ectocarpus siliculosus & $\mathrm{A}$ & Schoenoplectus tabernaemontanii & $\mathrm{A}$ \\
Elachista fucicola & $\mathrm{A}$ & Sphacelaria arctica & $\mathrm{P}$ \\
Elodea canadensis & $\mathrm{A}$ & Stictyosiphon tortilis & $\mathrm{A}$ \\
Eudesme virescens & $\mathrm{A}$ & Zannichellia palustris & $\mathrm{A}$ \\
Fucus radicans & $\mathrm{P}$ & Zostera marina & $\mathrm{P}$ \\
Fucus vesiculosus & $\mathrm{P}$ & Tolypella nidifica & $\mathrm{A}$ \\
Furcellaria lumbricalis & $\mathrm{P}$ & Ulva intestinalis & $\mathrm{A}$ \\
Halosiphon tomentosus & $\mathrm{A}$ & Ulva prolifera & $\mathrm{A}$ \\
Hildenbrandia rubra & $\mathrm{P}$ & Urospora penicilliformis & $\mathrm{A}$ \\
Leathesia difformis & $\mathrm{A}$ & & \\
& & &
\end{tabular}


phytobenthos community along the whole transect is calculated based on dry biomass of attached erect vegetation aggregated over the whole transect (Table 2).

\subsection{Determination of reference conditions and establishments of water quality class boundaries}

Type specific reference conditions were defined for abovementioned metrics mostly in combination of historical data and expert judgement. Historical data are available from years 1961-1978 for maximum depth of vegetation and Fucus vesiculosus $[9,10]$. Unfortunately no previous datasets with acceptable data quality exist for the most of the Estonian coastline. The amount and quality of the historical data vary in different areas. For some types, where historical data was insufficient, modelling was used. In these cases data from recent monitoring surveys were used to establish functional relationships of phytobenthos parameters, water quality indicators and reference conditions of pressure variables (nutrient concentrations, Secchi depth etc.).

Table 3: Type specific reference conditions and water quality class boundaries for the single phytobenthos metrics and EPI.

\begin{tabular}{|c|c|c|c|c|c|c|c|}
\hline Metric & Unit & $\begin{array}{l}\text { Ref. } \\
\text { cond. }\end{array}$ & High & Good & Moderate & Bad & Poor \\
\hline $\begin{array}{l}\text { EPI EQR } \\
\text { classes }\end{array}$ & - & & $>0.8$ & $0.8-0.5$ & $<0.5-0.3$ & $<0.3-0.1$ & $<0.1$ \\
\hline \multicolumn{8}{|c|}{ Type 1: Southeastern Gulf of Finland } \\
\hline $\begin{array}{l}\text { Vegetation } \\
\text { depth }\end{array}$ & $\mathrm{m}$ & 10 & $>8.0$ & $8.0-5.0$ & $<5.0-3.0$ & $<3.0-1.0$ & $<1.0$ \\
\hline Fucus depth & $\mathrm{m}$ & 5 & $>4.0$ & $4.0-2.5$ & $<2.5-1.5$ & $<1.5-0.5$ & $<0.5$ \\
\hline Perennials \% & $\%$ & 85 & $>68$ & $68-42.5$ & $\begin{array}{c}<42.5- \\
25.5\end{array}$ & $<25.5-8.5$ & $<8.5$ \\
\hline \multicolumn{8}{|c|}{ Type II: Pärnu Bay } \\
\hline $\begin{array}{l}\text { Vegetation } \\
\text { depth }\end{array}$ & $\mathrm{m}$ & 5 & $>4.0$ & $4.0-2.5$ & $<2.5-1.5$ & $<1.5-0.6$ & $<0.5$ \\
\hline Perennials \% & $\%$ & 60 & $>48$ & $48-30$ & $<30-18$ & $<18-6$ & $<6$ \\
\hline \multicolumn{8}{|c|}{ Type III: Western Gulf of Finland } \\
\hline $\begin{array}{l}\text { Vegetation } \\
\text { depth }\end{array}$ & $\mathrm{m}$ & 15 & $>12.0$ & $\begin{array}{c}12.0- \\
7.5 \\
\end{array}$ & $<7.5-4.5$ & $<4.5-1.5$ & $<1.5$ \\
\hline Fucus depth & $\mathrm{m}$ & 7 & $>5.6$ & $5.6-3.5$ & $<3.5-2.1$ & $<2.1-0.7$ & $<0.7$ \\
\hline Perennials \% & $\%$ & 90 & $>72$ & $72-45$ & $<45-27$ & $<27-9$ & $<9$ \\
\hline \multicolumn{8}{|c|}{ Type IV: Western Archipelago } \\
\hline $\begin{array}{l}\text { Vegetation } \\
\text { depth }\end{array}$ & $\mathrm{m}$ & 15 & $>12.0$ & $\begin{array}{l}12.0- \\
7.5\end{array}$ & $<7.5-4.5$ & $<4.5-1.5$ & $<1.5$ \\
\hline Fucus depth & $\mathrm{m}$ & 7 & $>5.6$ & $5.6-3.5$ & $<3.5-2.1$ & $<2.1-0.7$ & $<0.7$ \\
\hline Perennials \% & $\%$ & 90 & $>72$ & $72-45$ & $<45-27$ & $<27-9$ & $<9$ \\
\hline \multicolumn{8}{|c|}{ Type V: Väinameri } \\
\hline Fucus depth & $\mathrm{m}$ & 7 & $>5.6$ & $5.6-3.5$ & $<3.5-2.1$ & $<2.1-0.7$ & $<0.7$ \\
\hline Perennials \% & $\%$ & 70 & $>56$ & $56-35$ & $<35-21$ & $<21-7$ & $<7$ \\
\hline \multicolumn{8}{|c|}{ Type VI: Gulf of Riga } \\
\hline $\begin{array}{l}\text { Vegetation } \\
\text { depth }\end{array}$ & $\mathrm{m}$ & 12 & $>9.6$ & $9.6-6.0$ & $<6.0-3.6$ & $<3.6-1.2$ & $<1.2$ \\
\hline Fucus depth & $\mathrm{m}$ & 5 & $>4$ & $4-2.5$ & $<2.5-1.5$ & $<1.5-0.5$ & $<0.5$ \\
\hline Perennials \% & $\%$ & 80 & $>64$ & $64-40$ & $<40-24$ & $<24-8$ & $<8$ \\
\hline
\end{tabular}


The boundary setting system is based on the reference condition and a deviation of the acceptable reference conditions. According to OSPAR Common Procedure for Identification of the Eutrophication Status of the Maritime Area, the generally acceptable deviation from background concentrations or reference conditions is $50 \%[11,12]$. Boundaries between classes are determined according to scenario $\mathrm{C}$ (acceptable deviation from reference conditions 50\%) [13]. The deviations from reference conditions and boundaries for all parameters and classes are given in table 3 .

\subsection{Assessment method}

For the calculation of the Estonian Phytobenthos Index (EPI) the average values of parameters of each transect are used (Fig. 2). Normalized EQRs of three metrics were calculated using the formula:

$$
\mathrm{EQR}_{\text {metric }}=\frac{\left(\mathrm{P}_{\mathrm{x}}-\mathrm{P}_{1}\right) \mathrm{x}\left(\mathrm{E}_{\mathrm{u}}-\mathrm{E}_{1}\right)}{\left(\mathrm{P}_{\mathrm{x}}-\mathrm{P}_{1}\right)}+\mathrm{E}_{1}
$$

$\mathrm{P}_{\mathrm{x}}-$ measured value of parameter

$\mathrm{P}_{1}$ - lower class border of parameter

$\mathrm{P}_{\mathrm{u}}$ - upper class border of parameter

$\mathrm{E}_{1}$ - lower class border of $\mathrm{EQR}$ value

$\mathrm{E}_{\mathrm{u}}$ - upper class border of $\mathrm{EQR}$ value.

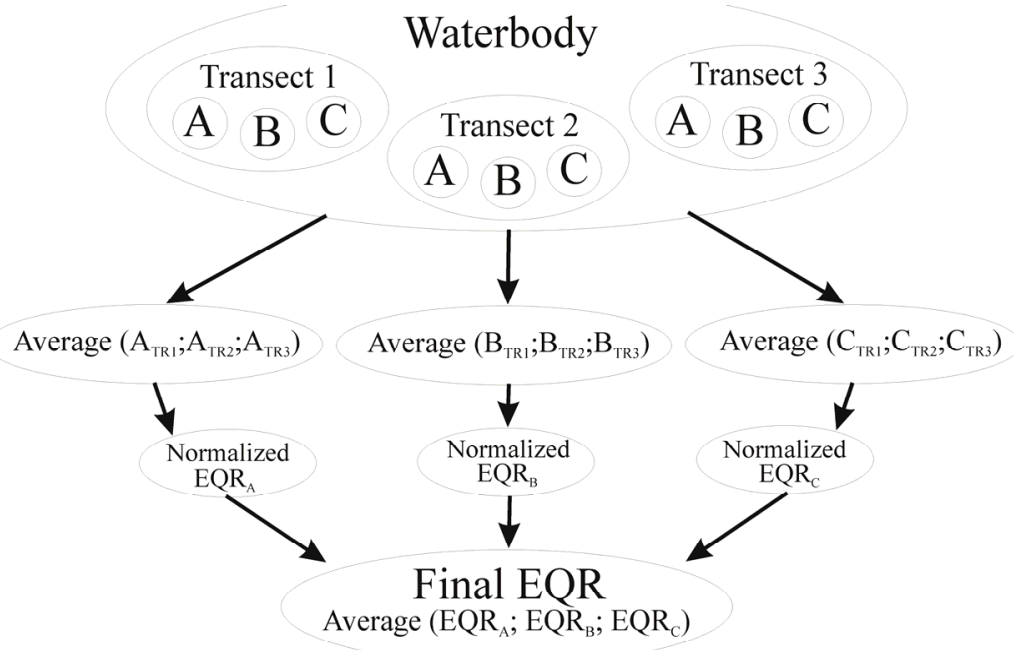

Figure 2: Conceptual scheme of EPI for final EQR calculations. Metrics: A vegetation depth limit, B - Fucus depth limit, $\mathrm{C}$ - proportion of perennials. 
For the final EQR average of metrics EQRs were used (Fig. 2). So the final assessment is performed using the aggregated data from two to three metrics and three monitoring areas from each water body.

\section{Discussion}

Currently, most EU countries have implemented the requirements of WFD and have established the water quality classification schemes for their coastal waters [14]. There is no unified guidance and methodological conditions set harmonising the actual monitoring methods and monitoring parameters/metrics but at the same time the results of the assessment and assessment schemes are going to be intercalibrated between countries. Special focus is set to ensure comparability of assessment results between countries. In the Baltic Sea variety of approaches is currently used in phytobenthos monitoring systems and water quality assessment schemes developed for the purpose of the WFD. These approaches differ between the countries and the regions of the Baltic Sea [14]. Estonian phytobenthos monitoring scheme was developed in the middle of 1990ies in close cooperation with Swedish and Finnish experts and was based on methodological guidelines published by Kautsky [15-17]. Monitoring methods follow the principles of the Phytobenthos Monitoring Guidelines adopted by HELCOM [8]. The results of Estonian phytobenthos monitoring programme showed the suitability of these methods for use in water quality assessment schemes already before the implementation phase of WFD [18]. So, for the purpose of the water quality assessment scheme required by the WFD the theoretical background proved to be relevant for the particular sea area was used (e.g. $[19,20])$ and the formalised assessment system created following the normative definitions of WFD.

The established assessment system follows all the requirements set by the WFD, describing the changes in distribution pattern, structure of the communities and variability of sensitive species in relation to changes in water quality characteristics. In the case of the Baltic Sea, in most cases the ruling anthropogenic pressure is eutrophication and the described assessment system responds well to the changes in the eutrophication level [8].

\section{Acknowledgements}

The Estonian phytobenthos monitoring programme is financed by the Estonian Ministry of the Environment as a subproject of the Estonian Marine Monitoring Programme. This study was also supported by the Estonian Science Foundation grant no. 8775 and target financed project SF0180013s08 of the Estonian Ministry of Education. We want to thank our colleagues contributing to the performance and development of the Estonian phytobenthos monitoring programme by assistance in the field and laboratory. 


\section{References}

[1] Directive 2000/60/EC of the European Parliament and of the Council of 23 October 2000 establishing a framework for Community action in the field of water policy. Off. J. Eur. Communities, L372, pp. 1-73, 2000.

[2] Carbiener, R., Trémolières, M., Mercier, J. L. \& Ortscheit, A. Aquatic macrophyte communities as bioindicators of eutrophication in calcareous oligosaprobe stream waters (Upper Rhine plain, Alsace). Vegetatio, 86, pp. 71-88, 1990.

[3] Orfanidis, S., Papathanasiou, V., Sabetta, L., Pinna, M., Gigi, V., Gounaris, S., Tsiagga1, E., Nakou, K. \& Theodosiou1, T. H. Benthic macrophyte communities as bioindicators of transitional and coastal waters: relevant approaches and tools. Transit. Waters Bull., 3, pp. 45-49, 2007.

[4] Rönnberg, C. \& Bonsdorff, E. Baltic Sea eutrophication: area-specific ecological consequences. Hydrobiologia, 514(1), pp. 227-241, 2004.

[5] Torn, K., Krause-Jensen, D. \& Martin, G. Present and past depth distribution of bladderwrack (Fucus vesiculosus) in the Baltic Sea. Aquatic Botany, 84(1), pp. 53-62, 2006.

[6] CIS Working Group 2.4. (Coast). Guidance on typology, reference conditions and classification systems for transitional and coastal waters, http://www.eutro.org/documents/wfd\%20cis $2.4 \% 20$ (coast) $\% 20$ guidance $\% 2$ 0on\%20tcw.pdf

[7] Lips, U. Eesti rannikumere looduslikud tü̈̈bid ja veekvaliteedi klassid. Eesti Mereakadeemia Toimetised, 2, pp. 62-73, 2005.

[8] Guidelines for monitoring of phytobenthic plant and animal communities in the Baltic Sea. Annex for HELCOM COMBINE programme, HELCOM, http://www.helcom.fi/stc/files/CombineManual/PartC/AnnexC9.pdf

[9] Trei, T. Lääne-Eesti rannikuvete fütobentos. Tallinn: Doctoral thesis, pp. 1164, 1973.

[10] Kukk, H. Benthic vegetation of the Gulf of Finland along the coastal waters of Soviet Union. Tallinn: Doctoral thesis, pp. 1-209, 1979 (in Russian).

[11] 2003 Strategies of the OSPAR Commission for the Protection of the Marine Environment of the North-East Atlantic. II - Eutrophication, $\mathrm{http}: / /$ www.ospar.org/content/content.asp?menu=00120000000070_000000 000000

[12] Ändersen, J. H., Conley, D. J. \& Hedal, S. Paleo-ecology, reference conditions and classification of ecological status: The EU Water Framework Directive in practice. Mar. Pollut. Bull., 49, pp. 282-290, 2004.

[13] Andersen, J. H., Schlüter, L. \& Ærtebjerg, G. Coastal eutrophication: recent developments in definitions and implications for monitoring strategies. J. Plankton Res., 28, pp. 621-628, 2006.

[14] Baltic Sea GIG. Coastal and transitional waters. WFD Intercalibration Phase 2: Milestone 4 report. Coastal and transitional waters.

[15] Kautsky, H. Factors structuring phytobenthic communities in the Baltic Sea. Akademitryck, Edsbruk, pp. 1-30, 1988. 
[16] Kautsky, H. Quantitative distribution of plant and animal communities of the phytobenthic zone in the Baltic Sea. Contributions from the Askö laboratory: Stockholm, pp. 1- 80, 1989.

[17] Kautsky, H. Quantitative distribution of sublittoral plant and animal communities in the Baltic Sea gradient. Biology and Ecology of Shallow Coastal Waters, eds. A. Elefteriou, A. Ansell \& C. Smith Jr., Olsen \& Olsen: Fredensborg, pp. 23-31, 1995.

[18] Martin, G., Torn, K., Kotta, J. \& Orav-Kotta, H. Estonian marine phytobenthos monitoring programme: preliminary results and future perspectives. Proceedings of the Estonian Academy of Sciences. Biology. Ecology, 52(2), pp. 112-124, 2003.

[19] Martin, G. Phytobenthic communities of the Gulf of Riga and the Inner Sea of the West-Estonian Archipelago. Tartu University Press: Tartu, pp. 1-139, 2000.

[20] Martin, G.; Torn, K. Classification and description of phytobenthic communities in the waters of the West-Estonian Archipelago Sea. Hydrobiologia, 514(1-3), pp. 151-162, 2004. 